\title{
Role of language assessment interval duration (LAID) in optimization of language development in children with cochlear implant: A systematic review
}

\author{
Vijay Kumar ${ }^{1}$ and Rachna Mehta ${ }^{2}$ \\ ${ }^{1}$ Amity University Haryana \\ ${ }^{2}$ Amity University
}

August 12, 2020

\begin{abstract}
Purpose: Early fitting of cochlear implant (CI) enables longer access of the critical period for language stimulation. In CI research, language assessment interval duration (LAID) which is a time gap between two language assessment phases, has been widely documented from the age of 2 months to 5 years and beyond. Thus, the objective of this review was to explore the potential role of the LAID in development of overall language outcomes. Method: A total of 1577 research articles were selected based on the age of implantation (AOI) below 24 months, at least two sessions of speech therapy per week, and occurrence of at least two formal language assessments. Twenty-one articles, consisting of 635 children with CI, were shortlisted for this review. Based on the LAID, the selected articles were classified into three categories based on AOI: $<6$ months, between $6-24$ months and $>24$ months. Result: Children with LAID of $<6$ months performed better in language development in comparison of the other two categories. The shorter LAID of six months enables real-time, periodic feedback to the language stimulating program which can fasten the growth of speech and language. Conclusion: Based on the specific clinical protocol, participant's availability, cost, and insurance cover the LAID is inconsistently practiced. Thus, the need of the development of a precise clinical protocol on the LAID is warranted. A shorter duration of the LAID of six months can optimize language outcomes in the children with early implantation, leading to enhancement of the CI effectiveness.
\end{abstract}

\section{Hosted file}

MS_CI_Review.doc available at https://authorea.com/users/350392/articles/475249-role-oflanguage-assessment-interval-duration-laid-in-optimization-of-language-development-inchildren-with-cochlear-implant-a-systematic-review

\section{Hosted file}

Table 1.doc available at https://authorea.com/users/350392/articles/475249-role-of-languageassessment-interval-duration-laid-in-optimization-of-language-development-in-childrenwith-cochlear-implant-a-systematic-review

\section{Hosted file}

Table 2.doc available at https://authorea.com/users/350392/articles/475249-role-of-languageassessment-interval-duration-laid-in-optimization-of-language-development-in-childrenwith-cochlear-implant-a-systematic-review

\section{Hosted file}


Table 3.doc available at https://authorea.com/users/350392/articles/475249-role-of-languageassessment-interval-duration-laid-in-optimization-of-language-development-in-childrenwith-cochlear-implant-a-systematic-review

\section{Hosted file}

Figure 1.doc available at https://authorea.com/users/350392/articles/475249-role-oflanguage-assessment-interval-duration-laid-in-optimization-of-language-developmentin-children-with-cochlear-implant-a-systematic-review 